\title{
Comparison of "The Parties" Aspect in Determining The Legitimacy of Sale and Purchase Transactions on Online Business Seen from Islamic Law and Civil Law of Indonesia
}

\author{
Astika Nurul Hidayah \\ University of Muhammadiyah Purwokerto \\ Email: astikanurul87@gmail.com
}

\begin{abstract}
The development of technology brings lots of new things which influence the development of civilization, including the internet that leads a very significant impact for the community. In the field of trade, it provides convenience to make transactions without any need of personal encounter between the seller and the buyer. The sale and purchase taking place have to be lawful and binding on the parties, the rights of the parties to be protected by law. In a case of a dispute, the resolution can be made in legal channels in accordance with the prevailing regulations. For this purpose, the sale and purchase transactions conducted on online business must be legitimate in the eyes of the law, both Islamic Law and Civil Law of Indonesia. One of the important determinants of the transaction validity is the subject or the parties in the sale and purchase. Although both laws put the aspects of the subject or the parties as one of the determinants of its validity, there are differences between Islamic Law and Civil Law which have an impact on the legal consequences of the contract or agreement in the sale and purchase transactions.
\end{abstract}

Keywords: Legality, Akad (Islamic Agreement), Agreement, Sale and Purchase

\section{INTRODUCTION}

The rapidity of modern science developed by scientists and academics is directly correlated with the technological advancements that sustain most of human life on earth. Technology [1] is a design for instrumental action that reduces the uncertainty in cause-effect relationship involve in achieving a desired outcome. The product of technology such as computers is very crucial and inseparable from modern human life today including the internet. In 1994, the internet site grew and developed to 3000 page addresses, and the first time a virtualshopping or e-retail emerged on the internet. In addition to the variety of things offered by the online store, ways or methods of online business transactions are also growing.

Islam allows its umma to do transactions with the way of sale and purchase. Definition of sale and purchase according to Fiqh Sunnah, that trading according to language is exchange. According to Shari'a understanding, the sale is the exchange of property on the basis of mutual willingness, or transfer of property with a justified change. Purchasing and selling is a social interaction among humans based on harmonies and conditions that have been determined [2]. In essence, purchasing and selling is a contract of exchange of goods or objects that have benefits to its users, both parties have agreed on the agreement that has been made.

Related to the validity of the sale and purchase it must first consider about the contract as a foundation for forming a sale and purchase. The contract is derived from Arabic which means the bond or knot of both visible (hissyy) and invisible (ma'nawy) ties. While the contract by term is a mutual agreement or commitment both oral, gestures, and writing between two or more parties that have binding legal implications to implement it. Contract as a term in sharia economic law is a meeting of a consent submitted by one party with an agreement from another party which has a legal effect on the object of the contract [3]. Ijab (consent).

In addition to Islamic law, civil law in Indonesia also regulates the sale and purchase based on Book III Book of Civil Code (Civil Code). The sale and purchase is nothing but the conformity of will (wisovereensteeming) between the seller and the buyer regarding the goods and the price. Goods and price become essential of purchase and sale agreement. Without goods to be sold, it is impossible to purchase and sell. Conversely, if the goods of sale and purchase objects are not paid with a price, purchasing and selling is considered non-existent [4]. A requirement contract is a contract in which the buyer promises to buy a quantity of goods measured by the buyer's requirements [5]. Article 1458 of the Civil Code states that purchasing and selling shall be deemed to have taken place immediately after the persons have reached agreement on the item and its price, even though the item has not been delivered and the price has not been paid [6]. However, all types of agreements including sale and purchase must comply with the legal requirements provided for in Article 1320 of the Civil Code because it determines the legal status or validity of the treaties made by the parties. 
The validity of the contract in Islamic law is seen from the fulfillment of the requisites and terms of the contract, whereas in the Civil law it is viewed from the fulfillment of the valid requirements of the agreement. One of the same aspects in determining the legitimacy of contracts under Islamic law and Civil law is the parties that make the agreement.

\section{METHOD}

This research is a legal research conducted to analyze social problems through legal perspective. The approach method used in this research was qualitative method with sociological juridical approach (social legal approach). The sociological juridical study analyzes the mutual relationship between law and other social institutions that are doctrinal and empirical [7].

\section{RESULT}

Article 20 Paragraph (1) The Compilation of Sharia Economic Law (KHES) determines that a contract is an agreement in a treaty between two or more parties to perform and or not to commit certain legal acts. In relation to the validity of the contract, article 28 paragraph (1) of KHES determines that a legitimate contract is an agreement that the requisites and conditions are fulfilled. Therefore, the contract must comply with the provisions of Article 22 of KHES, namely the requisites of contract consisting of the parties with the intention, the object of the contract, the principal purpose of the contract, and the agreement. On the terms of the contract, the parties acting under Article 23 KHES are persons, partnerships, or business entities that have the capacity to perform legal acts.

Legal competency under Article 1 paragraph (3) KHES is the ability of legal subjects to perform acts that are deemed legally valid. While the criteria is considered to have legal competency under Article 2 KHES that has reached the lowest age of 18 (eighteen) years or ever married; and business entities which are legal entities or non-legal entities, may enter into legal action in the case of non-declared taflis / bankruptcy based on a court decision that has obtained permanent force of law. The parties doing the contract (aqidain) is one of the requisites to establish the contract [9]. Without aqidain as the legal subject, a contract is unlikely to materialize. The legal subjects consist of human and legal entity.

\section{Human}

Man as a legal subject must meet the requirements of competency (expertise) and authority (territory) for the contract to be made legitimate.

a. Ahliyah (expertise), in Islamic law the qualification requirement can be divided into 2 (two) i.e. (1) ahliyah al-wujub is one's competency to accept the law, and (2) ahliyahal-ada is the legal competency to act actively. It is therefore applied only to legal subjects who naturally have the capacity to do legal acts. The legal subject is divided into 2 (two) types, i.e. (a) imperfect competencies of legal acts that are applicable to the legal subjects when they are at the age of discernment which is a minimum requirement of competency for the parties who will hold the contract; (b) perfect competencies of legal acts that are applicable to the legal subjects from adulthood to death, and only after a person has a reasonable maturity (aqil) and reaches the age of adulthood (baligh). According to jumhur fuqaha (the majority of fiqh scholars, maturity is essentially known from the physical signs of ihtilam or menstruation. But if the signs do not appear, then maturity is marked by age that has reached 15 (fifteen) years [8].

b. Territory, is the authority possessed by legal subjects to perform legal acts. Authority is the power to use the rights to do some actions with all possible legal consequences.

\section{Legal Entity}

The term of legal entity (syakhshiahi' tibariyah hukmiyah) is not mentioned specifically in fiqh. But the existence of legal entities is justified in fiqh, although the term does not exist in the past [9]. The provision to make the legal entity as the legal subject must always be in line with the principles contained in the Qur'an and Sunnah. In the case of humans acting as representatives of the organs of such institutions or enterprises, but vertical accountability is restored to each individual practice. Humans acting on behalf of themselves and legal entities are the parties (aqidain) in the preparation of contracts. Therefore, the parties must qualify as aqidain in order that the contract can be valid and have legal consequences [10].

Based on the results of the analysis on the requisite as one of the indicators of the validity of the contract contained in drop shipping system, it can be concluded that by looking at each requisite of the contract that has been fulfilled with based on the data, the drop shipping system as a variant of purchasing and selling today is declared legitimate according to Islamic law.

In addition to Islamic law, the Civil Code is also applied in Indonesia to regulate civil affairs so that the rules of sale and purchase can be found in Book III of the Civil Code. If it is related to the legality of the sale and purchase transaction, it must be analyzed based on the validity of the agreement as stipulated in Article 1320 of the Civil Code i.e. agrees with those who commit themselves, the ability to make an engagement, a certain matter, and a lawful cause.

1. Agreeing with those who bind themselves, agreeing is the suitability of the seller (in this case is a dropshipper) with the buyer regarding the sale and purchase of goods offered by the dropshipper. Article 6 of the ITE Law specifies that in a dropshipping system, an agreement can be realized between the parties if the dropshipper offers its products online using view as attractive as possible and the information contained therein must be accessible, self-contained, and accountable so as to explain a situation. In addition, pursuant to Article 8 of the ITE 
Agreement, the agreement may be related to the time of sending the buyer's consent message to the dropshipper if the buyer has fulfilled the shipping procedure established by the dropshipper completely, clearly and honestly so that an agreement can be reached between the dropshipper and the buyer.

2. The competency to make an engagement is regulated in Article 1329 of the Civil Code, that is, each person is competent to make engagements, provided that the person is not included in the category of person who is declared incompetent by law. Anyone who is otherwise competent to enter into an agreement can be seen in article 1330 of the Civil Code by interpreting a contrario of that article, so that those who are otherwise proficient are those who are adults and those who are not under the amnesty. In the case of adulthood is the requirement of someone who is declared proficient then must see a contrario on the rules that regulate the maturity of Article 330 of the Civil Code that is stated that adults are people who are twenty-one years old or have been married. In the event of a breakup of marriage in a person who is not yet twenty-one years old then still declared adults.

\section{CONCLUSION}

To find out the validity of sale and purchase transactions using drop shipping system in online business, it is obtained basic arrangement in Islamic Law that is in Compilation of Islamic Economic Law (KHES) which is Islamic Law that becomes positive law in Indonesia. Meanwhile in the Civil Code, drop shipping is regulated in the Civil Code, the Book of Commercial Law and the Law of Information and Electronic Transactions. In the Civil Code it is obtained arrangements regarding the understanding of the agreement, the legal terms of agreement with the qualification of each point, and the arrangement of sale and purchase. The Book of Commercial Law regulates the broker or commissioner, and the Law of Information and Electronic Transactions regulates the obligation of the drop shipper to reach an agreement, and the rule on the third point of the terms of the agreement.

In Islamic Law, drop shipping is subject to the rules of requisites and the terms of the contract to determine how its validity is. Based on the results of this research, sale and purchase transaction in the drop shipping system is declared legal/valid because it has fulfilled the requisites and conditions of the contract. Meanwhile in the Indonesia's Civil Code which is subject to the Civil Code, the drop shipping system is declared illegal/invalid because it does not meet the requirement of maturity on the second legal requirement that is legal competency so that the status of the agreement could be canceled. This means that even if the agreement is invalid, it persists and binds the parties as long as there is no request for cancellation of the parties to the agreement. While if the parties have met the aspect of maturity on the legal requirements of legal competence, then the sale and purchase transaction on the drop shipping system is declared legal/valid.

Having understood the validity of the sale and purchase transactions, the parties involved in the sale and purchase transactions using the drop shipping system must pay close attention to the validity criteria of both Islamic Law and Civil Law of Indonesia in order that the purchasing and selling that occurs between the parties becomes lawful in order to bind the parties. In addition, the rights of the parties to be protected by law, and if there is a dispute it can be resolved by a legal path in accordance with the regulations applied in Indonesia.

\section{REFERENCES}

[1] Agoeng Noegroho, 2010, Teknologi Komunikasi, Yogyakarta, Grahallmu.

[2] Sayyid Sabiq 1989, Fiqih Sunnah XII, alih bahasa Kamaludin A. Marzuki, Bandung, PT Alma'arif.

[3] Shobirin, 2015, Jual Beli dalamPandangan Islam, Jurnal Bisnis dan Manajemen Islam, Vol 3 No. 2.

[4] EvitaIsretno, 2011, Pembiayaan Mudharabah dalam Sistem Perbankan Syariah, Jakarta, Cintya Press.

[5] Santonius Tambunan, 2016, Mekanisme dan Keabsahan Transaksi Jual Beli E-Commerce Menurut Kitab Undang-Undang Hukum Perdata, Badamai Law Journal, Vol. 1 Issues 1.

[6] Sheldon Kleinand David DeVine,2012, Contract Law and the Changing Business Needs of the Automotive Supply Chain: The Problem of Dual Source Requirements Contracts, The Michigan Business Law Journal, Volume 32 Issue 3.

[7] Daniel Alfredo Sitorus, 2015, Skripsi, Universitas Atma Jaya Perjanjian Jual Beli Melalui Internet (E-Commerce) Ditinjaudari Aspek Hukum Perdata.

[8] Ronny Hanitijo Soemitro, 1990, Metode Penelitian Ilmu Hukum, Jakarta, Ghalia Indonesia.

[9] Burhanuddin S., 2009, HukumKontrakSyariah, BPFE-Yogyakarta, Yogyakarta.

[10] Teungku Muhammad Hasbi Ash Shiddiqqy,2001, PengantarFiqhMuamalah, CetakanKeempat, PT. PustakaRizki Putra, Semarang. 